Uşak Üniversitesi Sosyal Bilimler Dergisi

$2014,7(1), 87-114$

\title{
Zola'nın Gerçek Romanında Bağnazlığa Karşı Hoşgörü, Özgür Düşünce, Demokrasi ve Adalet Yanlısı Uygar Toplum Yaratma Çabası
}

Rıfad GÜNDAY*

Hoşgörü, en iyi dindir.

Victor Hugo

Hoşgörü, uygarlı̆̆ın biricik sınavıdır. Arthur Helps

Adaletin olmadı̆̆g yerde ahlaktan bahsedilemez.

Montaigne

\section{Özet}

Emile Zola, Gerçek adlı romanında Fransız toplumunda Dreyfus Davası sürecinde yaşanan haksızlıkları ve kendisinin de içinde olduğu bir grup insanın verdiği mücadeleyi kurgulayarak efsaneleştirmeye çalışmıştır. Romanın kahramanlarından Marc öğretmen, Yahudi kökenli olduğu için haksız yere suçlanarak ömür boyu hapse mahkûm edilen öğretmen Simon'un suçsuzluğunu ortaya çıkarmak için mücadele eder. İşbirliği içerisinde hareket eden çeşitli güç odakları toplumda baskı oluşturarak toplumu istedikleri gibi yönetmeye çalışmaktadırlar. Özellikle tarikatçı papazlar gerçek din ile bağdaşmayan davranışlar sergileyip çıkarları doğrultusunda birçok haksızlık yapabilmekte, masumları suçlayıp suçlulardan yana taraf tutabilmekteler. Adeta karanlık güç odağı haline gelen tarikatçı kilise papazları ve bu okullardan mezun memurlar, Fransız devletinin birçok kurumuna sızmış ve gizliden gizliye örgütlü bir şekilde çalışmaktadırlar. Romanda cinayet ve ırza geçme suçlarını işleyen tarikat okulu öğretmeni Gorgias olmasına karşın, korunmaktadır. Romanda insancıl değerlerin, özellikle de din adına hareket edenler tarafından yok edilişinden hareketle, toplumun değerler bağlamında yozlaşmasından söz edilmektedir. Yazar, vermeye çalıştı̆̆ı ideolojiye felsefi bir boyut kazandırmakta ve soruna hümanist bir perspektiften bakmaktadır. İnsanlığın gelecekte mutlu yaşam sürdürebilmesi için romanda ele alınan dini taassup, ırkçılık ve ötekileştirme gibi sorunların çözümü çok önem arzetmektedir. Zola, toplumda askeri, dini, siyasi ve ekonomik açıdan güçlü otoritelerin dayatma ve isteklerinin değil, gerçek ve evrensel adaletin

\footnotetext{
* Doç. Dr. Ondokuz Mayıs Üniversitesi Eğitim Fakültesi Fransız Dili Eğitimi Ana Bilim Dalı
} 


\section{R. GÜNDAY $\mid 88$}

hüküm sürmesinin, insanlığın geleceğinin güvence altına alınabilmesi ve insan onurunun korunması noktasında önemine dikkat çekmek istemiştir.

Anahtar Kelimeler: Taassup, hoşgörü, özgür düşünce, demokrasi, adalet.

\section{The Effort for Creating a Civilized Society Against Bigotry, Defending Tolerance, Free Thought, Democracy and Justice}

\section{in Truth (Vérité) by Zola}

In his novel entitled Truth, Zola tries to mythologize the struggle of a group of persons, one of whom is the writer himself, against injustices in French society during Dreyfus Case, fictionalizing it. One of the major characters of the novel, Marc the teacher, struggles for proving the innocence of Simon, the teacher, accused falsely and sentenced to life imprisonment because of his Jewish origin. Various power groups behaving cooperatively try to manipulate society by creating pressure. Sectary priests in particular have displayed behaviours incompatible with real religion, wrongdone for their own interests, condemned the innocent while taking sides with the guilty. Sectary priests and clerks becoming dark power groups in a sense have infiltrated many government institutions and worked secretly in an organized manner. Although Gorgias, the teacher of the sect school, have raped and murdered, he has been protected. The novel deals with the deterioration of social values due to the abuse of these values by those behaving on behalf of religion. The writer adds a philosophical dimension to the ideology and approaches the problem humanistically. The solution of the such problems as religious fanaticism, racism and othering dealt with in the novel is of great importance so that people lead a happy life in future. Zola wants to take attention to the importance of the prevalence of real and universal justice in society, instead of the desires and imposition of military, religious, political and financially powerful authorities for the protection of human dignity, securing the future of humanity.

Key Words: fanaticism, tolerance, free thought, democracy, justice.

\section{Giriş}

Değişik edebi türlerde eserler veren Emile Zola, yalnız Fransız edebiyatının değil, dünya edebiyatının da en ünlü yazarları arasında yer almaktadır. Natüralizm akımının şefi olarak kabul edilir. Özellikle roman türünde verdiği eserlerinde döneminin toplumsal sorunlarını neden-sonuç ilişkisi bağlamında ele almaktadır. İrdelediği evrensel sorunlarla ölümsüzlüğünü garantileyen Zola'nın eserleri, güncelliklerini korumayı 
sürdürmektedir. Romanlarından yaklaşık yüz elli film ve televizyon dizisi uyarlanmıştır.

Basını yakından takip eden Zola, döneminin, özellikle de 19. yüzyılın ikinci yarısında Fransız toplumunda yaşanan olaylara kayıtsız kalmaz, gerek romanlarında ve gerekse Le Figaro, L'Aurore gibi gazetelerde yazdığı makalelerinde toplumsal sorunları irdeler. Yaşadığı dönemin olaylarının iyi bir gözlemcisidir. Cumhuriyet yanlısı olan Zola, imparatorluğa karşı mücadele eder. Ona göre insanların özgür bir birey olarak yaşamlarını sürdürebilmeleri açısından en uygun yönetim şekli demokratik cumhuriyettir.

Eserlerinin genel içeriklerine bakıldığında üç grupta toplanmaktadir: Les Rougon-Macquart serisinde yer alan 20 romaninda Zola 1851 Devlet Darbesiyle başlayıp 1870 Sedan bozgununa kadar süren İkinci İmparatorluk Dönemi Fransız toplumunun bir tablosunu yansıtmaya çalışır. Aynı zamanda bu seride yer alan romanlarda Rougon ve Macquart ailelerinin beş kuşağı içine alan yaşamlarından söz edilir. Söz konusu dönemi anlatırken hiç kuşkusuz romanlarını yazdığı dönemlerin toplumsal sorunlarına da duyarsız kalmaz. (Becker ve diğerleri, 1993 :47).

Zola'nın ikinci seride yer alan romanları Üç Kent (Les Trois Villes) adını taşımaktadır. Bu serinin kahramanı papaz Froment'ın üç oğlu, Mathieu, Luc ve Marc Froment, insanlığa hizmet edebilme adına Mesih gibi dünyayı değiştirmeyi görev edinirler. (www.nuveforum.net).

Zola'nın Dört İncil (Quatre Evangiles) başlığını taşıyan Verimlilik, Emek, Gerçek, Adalet (Fécondité, Travail, Vérité et Justice) romanlarından oluşan seride olaylar, Pierre ve Marie Froment'ın oğullarının etrafında gelişmektedir. Bu romanlar, Zola'nın toplumsal felsefesini özetlemektedir.

Söz konusu üç seri "insanlık tarihinin üç ayrı dönemini (geçmiş, bugün ve gelecek) temsil eder" (www.haberbuketi.com/emile-zolabiyografi,16.htm). Rougon-Macquart serisinde yer alan romanlarda belli belirsiz iyimserlik söz konusu iken, Üç Kent serisi romanlarının kahramanları, insanlığın sorunlarıyla ilgilenip dünyayı değiştirmeye çalışırlar. Dört İncil adını verdiği son seride yer alan romanlarında ise Zola, 20. yüzyıl insanının, akılcılığı ön planda tutarak toplumları geriye götüren tutum ve davranışlardan kurtulacağına inanır. Böylece Zola'nın, uygar toplum yaratma konusunda umudunu kaybetmediği görülmektedir. Son serinin 1899'da yayınlanan Verimlilik adlı romanında toplumsal yaşamdaki çöküntüyü ve yaşamın mutsuzluklarını dile getirmektedir. 1901'de yayınlanan Emek adlı romanı adeta sosyalizmin incili gibidir. Yazar bu romanını toplumsal ilerleme ve endüstriyel gelişimler konusuna adar. 


\section{R. GÜNDAY $\mid 90$}

Dreyfus Olayı'nın kurgulanarak edebiyata aktarılması olan ve laik devlet okulları ile kilise okulları arasındaki mücadeleyi anlatan Gerçek romanı yazarın ölümünden sonra 1903'te yayınlanırken, serinin son romanı Adalet, taslağ1 bittikten hemen sonra yazarın ölümüyle yarım kalır. (www.nuveforum.net). Geleceğin hedeflendiği son seride yer alan romanlarında Zola, hoşgörünün, özgür düşüncenin ve mutlak adaletin hüküm sürdüğü toplumlarda ancak bireylerin mutlu, huzurlu ve üretken olabileceği düşüncesini vurgulamaktadır.

Gerçek romanında Zola, Fransa'da Dreyfus Olayı sonucu yaşananları romanlaştırır. Yazar gerçekle kurmacayı ustaca karıp, romanında tarihsel ve toplumsal bir gerçeğe ayna tutarak bir yandan sorunu evrenselleştirirken, diğer yandan da eserini ölümsüzleştirmeyi başarmıştır. Çünkü o, Fransız toplumunda yaşanan bir tarihi olaydan yola çıkarak tüm insanlığı ilgilendiren önemli bir sorun olan bağnazlığı bütün yönleriyle ve toplumun tüm katmanları bağlamında ele almaktadır. Ona göre sorunun tek çözüm yolu da laik eğitim yoluyla insanları küçükken iyi eğitmekten ve onlara hoşgörü kültürü kazandırmaktan geçmektedir.

Gerçek romanı, "doğrudan doğruya Dreyfus olayına bağlıdır, SimonDreyfus kahramanlarından Gorgias-Esterhazy kahramanlarına kadar bu olayın serbest uyarlamasıdır. Eserdeki temel karşıtlık hiç kuşkusuz geleceğin güçleriyle karanlıkçılığın çatışmasıdır. Sürekli mücadeleye mahkûm cesur eğitimciler ya da kurbanlar, aynı zamanda kurnaz, entrikacı, güç ve paraya susamış açgözlü, sapık insanlar dikkat çeker... Dolayısıyla Zola bir mesaj vermiştir: Halka gerçeği göstermek gerekir... Gerçek, gerçek üstüne namuslu ve akıllıca bir araştırmanın insani ve edebi bir kanitlamasıdır." (www.gunlukkitap.com/.../1623-gercek-978975885...). Zola gerçeğin gün ışığına çıkartılmasının ve adaletin yerini bulmasının uğraşını vermektedir (Guillemin, 1997:200). Gerçek romanında yaşananlar tıpkı Dreyfus Olayı gibi toplumsal bir cinayettir (Mourad, 2003:3). Zola, diğer romanlarında olduğu gibi bu romanında da, genelde Fransız İhtilali sonrası özelde ise 19. yüzyılın ikinci yarısı Fransa'sının toplumsal olaylarını, söz konusu dönemde tutucu ve dogma halini alan davranışların toplum üzerindeki etkisini ele almaktadır (Mittérand, 1990: 28). Gerçek adlı romanında, başta tarikatçı kilise çevreleri olmak üzere çağdaş düşünce ve demokrasi karşıtı tüm güçlerin toplumda sergiledikleri anti demokratik ve insanlık dışı tutumları bütün çarpıklıkları ile ortaya koymaya çalışır. Fransa'da gelecekte laiklik, demokrasi ve adalet yanlısı bir toplum yaratma amaciyla Dreyfus Davası'nda politik bir mücadele veren Zola, Gerçek romanında aynı mücadeleyi öğretmen kimliğine büründürdüğü roman kahramanı Marc aracılığı ile eğitim mücadelesine dönüştürür. Kiliseler, 
özellikle de tarikatlar, eğitim, toplum ve kamu üzerindeki etkilerini sürdürmek isterler. Romanda ele alınan laik eğitim dine dayalı eğitim ikilemi, 1904 yılında gerçekleşen Kilise ve Devlet işlerinin ayrılmasıyla son bulur. (Pagès, 2008 :114; Mitterand, 1995:31; Achard-Bayle, 2001:33). Zola'ya göre bağnaz tarikatçı kilise çevreleri ve okulları, insanlığın aydınlık geleceğini karartmaktadırlar. Huzurlu bir toplum oluşturmak için adaletin tek kurtuluş yolu olduğunu kanıtlamaya çalışan bu eser, gelecekte arzu edilen özgür düşünceli ve hoşgörülü bireylerden oluşan demokratik bir toplum yaratmaya yönelik bir laik eğitim romanıdır.

\section{Natüralizm Anlayışının Romana Yansıması}

Bir yazar olarak Zola, döneminde gelişme gösteren bilimsel gerçeklik ve felsefi yaklaşımlar sonucu 19. yüzyılın ikinci yarısında yaygınlaşan bilimsel belirlenimciliği benimser. Natüralizm akımının ilkelerine bağlı kalarak romanlarını yazan Zola, toplumun bilimsel bir incelemesini yapar. Çağdaşı Fransız düşünür Hippolyte Taine'in çevre ve kalıtımla ilgili görüşlerini, özellikle de aynı nedenler, aynı koşullar altında, aynı sonuçları doğurur düşüncesini özümser. Fransız fizyoloji bilgini Claude Bernard'ın 1865'te yayımlanan Deneysel Hekimlik Incelemesine Giris adlı yapıtı da Zola'nın yöntemini derinden etkiler. Zola'nın görüşlerini etkileyen bir diğer önemli kaynak ise G. St Hilaire'in insan ve hayvan, ortamın şekillendirdiği tek tür canlıdır yaklaşımıdır. Söz konusu akımın edebiyat eserlerindeki ilkelerini Zola, Deneysel Roman adlı kitabında açıklar. Doğa bilimlerinin edebiyata uygulanması şeklinde ortaya çıkan natüralist ilkeye göre roman, gerçeği yansıtmalı, yaşam koşulları, toplumsal ve siyasal çevreler üzerine her türlü belge ve deneye dayanmalıdır. (Mitterand, 1990 : 28-29; $\quad$ Sacquin,2002:56; $\quad$ www.haberbuketi.com/emile-zolabiyografi,16.htm). Zola, çevrenin ve koşulların birey üzerindeki ezici etkisi üzerinde durur. İnsanı belli koşullar içinde ele almakta, onun duygu ve düşünce dünyasını, yetiştiği doğal ve toplumsal çevrenin etkisi doğrultusunda çizmektedir. (www.giannaparadiso.com/Pages.aspx?konuID=1,).

Zola, bu çalışmada irdelediğimiz Gerçek adlı romanında gerçeğin araştırılmasına ve bilimsel/deneysel yöntemlerle ortaya konmasına büyük çaba sarf eder. Bunun yanında Zola özellikle, 16 yüzyıl rönesans ve reform hareketleri ile 18. yüzyıl aydınlanma çağı yazar ve düşünürlerinden esinlenir. Zola (1880:1), sanatı uygarlık durumunun bir ifadesi olarak değerlendirmektedir. "Tüm boyutlarıyla insanlığ Bireyler söz konusu devri özetleyen aktördürler. İnsanlarla ilgili önemli 


\section{R. GÜNDAY | 92}

analiz yapmakta ve tarih yazmaktayım" demektedir (Darcos, Agard ve Boireau, 1986:435). Balzac gibi Zola da döneminin tarihçisi gibidir.

Gerçek romanında doğal bilimlerin ortaya koyduğu soya çekim ilkesinin varlığından da söz edilebilir. Zira Marc öğretmenin kızının özgür düşünceli bir birey olarak kişiliğinin şekillenmesinde aldığı laik eğitimin yanı sıra, babasının genlerini taşıması nedeni ile babasına benzemesi de önemli bir etken olarak romanda vurgulanmaya çalışılmaktadır.

Zola, natüralizm sanat anlayışının temel ilkelerinden birisi olan, çevrenin kişiler üzerindeki etkisi ilkesini, mahalle baskısı ya da çevre baskısı şeklinde Gerçek romanında ele alınan sorunlar bağlamında açık bir şekilde vurgulamaktadır. "Zola'nın baş yapıtlarında adeta olayın mekanı, belgesi ve etkeni birlikte koşullanmaktadır." (Tadié, 1970: 78). Natüralist anlayışa göre birey, içinde yetiştiği toplumsal ve doğal çevrede biçimlenir. Bu nedenle, betimleme, doğalcı eserlerin en önemli anlatım biçimi olarak dikkat çekmektedir. (www.hikayeler.net/edebiyat/Sanat_Akimi/Naturalizm.asp). Yazı kadar görsel estetik yanı da ağır basan Zola, romanlarında olayları anlatmakla yetinmeyip betimleme sahnelerinde adeta olayların fotoğrafını çekmekte ve yaşananları görselleştirmektedir.

Dönemin Fransa'sının birçok köy, kent ve kasabasında olduğu gibi Maillebois kasasında da tarikatçı papazların ve yandaşlarının halk üzerinde etkileri söz konusudur. Bir tarikat yuvası haline gelen Maillebois'da özünde pek kilise ve tarikat yanlısı olmayan halk da çevre baskısından kaynaklanan çeşitli nedenlerden dolayı tarikat güçlerine boyun eğmektedir. Gerçek romanı, toplumsal olaylar üzerine çevrenin, özellikle etkin güçlerinin, bireyler ve yargı üzerindeki baskılarına yer verir. Dreyfus Davası'ndaki bazı aydınlar gibi Gerçek romanında da bazı insanlar çevre ve gerici güçlerin baskısından korktukları ve çıkarlarına zarar geleceği için, Simon öğretmenin suçsuzluğunu bilmelerine karşın onu maruz kaldığı adaletsizlikten kurtarmaya çalışan öğretmen Marc ile birlikte hareket etmekten çekinirler.

Eğitimsiz cahil halk koyun sürüsü gibi, çeşitli güçler tarafından kolayca güdülmektedir. Simon'un tutuklanması sırasında ve mahkemede, karanlık güçlerin yönlendirdiği halk vahşi hayvan sürüleri gibi bağırır ve Simon'a saldırırlar. Söz konusu olayların anlatıldığı sayfalarda Zola, cahil insanın hayvandan farksız olduğunu göstererek, adeta o dönem bazı doğa bilimcilerinin savunduğu insan ve hayvan çevrenin ya da eğitimin şekilldendirdiği tek tür canlıdır görüşünü benimser.

\section{Dreyfus Davasi/Olayı}

1894 yılında Fransız ordusunda ortaya çıkan gizli askeri belgelerin Alman Ataşeliğine sızdırılması olayında Yüzbaşı Dreyfus, Yahudi olması nedeniyle casusluk ve vatana ihanetle suçlanarak askeri yargının 
duyarsızlığına kurban gider. Önyargılı hazırlanan iddaanameye, Dreyfus'u kesin suçlu gösterebilmek için bir de Binbaşı Henry'nin sanığın el yazısını taklit ederek yazdığı sahte mektupla destek olunur. Kurallar çiğnenerek zanlının avukatlarına gösterilmeden, yargıçlara gizlice verilen dosyadaki bir el yazısına dayanarak Paris Savaş Konseyi, Dreyfus'u suçlu bulup ömür boyu hapis ve rütbesinin geri alınması cezasına çaptırır. 1899'da Rennes'de yeniden yargılama yapılır ve yeniden yargılama sürecinde de karanlık güçlerin mahkeme üzerindeki baskı ve yönlendirmeleri neticesinde Dreyfus yine suçlu bulunur. Dreyfus hüküm giyip Guyana'daki Şeytan adasına sürülmesine karşın, genelkurmaydan Alman Ataşeliğine bilgi akışının devam etmesi üzerine Genel Kurmay İstihbarat Birimi'nin başına getirilen Yarbay Picquart'ın sıkı takibi neticesinde, Alman Askeri Ataşesi'nin çöp kutusunda Fransız ordusuna ait bilgi içeren yeni bir belge bulunur. İstihbarat Servisi'nin araştırması sonucu, zevk düşkünü ve çok borcu olan komutan Binbaşı Esterhazy'den kuşkulanılır. Bu belgedeki el yazısı ile Dreyfus'un mahkûm olmasında rol oynayan gizli belgedeki yazı karşılaştırılır. Yarbay Picquart, mahkemeye sunulan gizli dosyadaki evrakın sahte olduğunu tespit eder ve durumu üstlerine bildirir. Ancak General Gonse olmak üzere üst rütbeli subaylar, ordunun zarar görmesini önlemek amacıyla bu gerçekleri dikkate almak istemezler, ayrıca yarbaya bildiklerini kimseye anlatmamasını, bir Yahudinin mahkûm olmasının önemli olmadığını söyleyerek suçun Dreyfus'un üstünde kalmasını benimserler.

Dreyfus olayında gerçekleri ortaya çıkaran komutan Yarbay Picquart, bu gerçeği saklayamayacağını bildirmesi üzerine kınanarak Tunus'un güneyine gönderilir. Bu durum üzerine Dreyfus'un ailesi hukuk mücadelesi başlatır. Bu süreçte yargılanmayı talep eden Esterhazy, üstlerinin desteğiyle bir Savaş Konseyi'nde yargılanır ve 1898'de beraat eder. Zola, suçsuz yere, Hristiyan dininden ve Fransız ırkından değil diye askeriye ve bağnaz çevrelerin tutumu neticesinde bir insanın mahkum olmasına isyan eder ve 1897 'den itibaren onu desteklemeye başlar. Hükümet, ordu ve kilise çevrelerinin bütün baskılarına karşın, masum bir insanı savunma mücadelesini sürdürür. Dreyfus Davası konusunda Le Figaro ve L'Aurore gazetelerinde gerçeğin ortaya çıması ve adaletin gerçekleşmesi uğruna büyük mücadele verir. En ses getirici çalışması, dava ile ilgili bir isyan çığlığı olarak Fransa Cumhurbaşkanına hitaben L'Aurore gazetesinde yazdığı "İtham Ediyorum" adlı açık mektuptur. Bu mektupta Zola nasıl bir adli hata yapıldığını anlatır. Kampanyaları susturulamayan Zola hakkında orduyu küçük düşürdüğü gerekçesiyle dava açılır. Yahudi düşmanı subaylar ve gerici kilise yanlılarının baskı ve yargıyı 


\section{R. GÜNDAY | 94}

yönlendirmeleri sonucu 1898 'de bir yıl hapis ve 3000 frank para cezasına çaptırılır. Mahkeme kararı kendisine tebligat yapılmadan arkadaşları Zola'yı Londra'ya gitmesi konusunda ikna ederler. Bir süre Londra'da yaşamak zorunda kalır. Davanın yeniden ele alınacağı kararı üzerine Fransa'ya geri döner. "Gerçek yürüyor ve hiçbir güç onu durduramayacak." sözleri, Dreyfus Davası ile ilgili Zola'nın sloganı olur ve bu başlık altında basında yazılar yazar. Bir kişi suçsuz yere ömür boyu hapse mahkûm edilerek ceza evinde yatırılırken, asıl suçlunun görevine devam edip toplum içerisinde özgürce dolaşması ve saygı görmesi Zola'ya göre kabul edilemez bir durumdur. Aydın olma sorumluluğuna sahip bir yazar, daha doğrusu her şeyden önce bir insan olma onuruna yakışan bir tavır takınarak hiç tanımadığı ancak masum olduğuna inandığı kendi ırkından ve dininden olmayan bir insanı uğradığı haksızlıktan kurtarma mücadelesinde saf tutar. "Zola, olayın kendisi için ırk değil, adalet sorunu olduğunu açılar." (Baysan, 2002: 185).

Söz konusu dava sürecinde Fransa iki kampa bölünür: Bir yanda Dreyfus'un masum olduğuna inanıp onu destekleyen aydınlar ve demokrat kesimler. Diğer yanda Dreyfus'u din ve vatan düşmanı göstermeye çalışan gerici güçler, ırkçılar ve üst düzey subaylar. Zira bu kesimlerin asıl amacı, toplumda hâkimiyetlerini rahatça sürdürebildikleri imparatorluk yönetimini Fransa' da yeniden hayata geçirmektir.

Bazılarına göre Dreyfus Davası sürecinde takındığı adalet yanlısı tavır, Zola'nın yaşamına mal olmuştur. Bu mücadelenin bedelini, 28 Eylül 1902'de Paris'teki evinde bacadaki tıkanıklık yüzünden uykuda karbon monoksit gazı zehirlenmesinden ölen Zola canıla öder (Winock, 1999: 3941; Bedel, 2002). Dreyfus'un suçsuzluğuna inananların çabası, parlemanto başkan yardımcısı ve yeni cumhurbaşkanının da desteği ile nihayetinde karşılık bulur. Yargitay, Dreyfus'un Yargıtayda yargılanmasına karar verir. “Jaures'in Meclis'e verdiği bir önerge sonucu Dreyfus yeniden yargılanır; 1906'da aklanarak orduya geri döner. Bu arada Clemenceau Başbakan, Picquart Savaş Bakanı olmuştur. Birkaç yıl önce Zola'yı vatan hainliğiyle suçlayan Meclis, kemiklerinin ulusal kahramanların yattığı Pantheon'a taşınmasına karar verir. Ancak gericiler, 1908'de düzenlenen bu törene gölge düşürmek isterler. 5000 eylemci yolları keser; tören sırasında Binbaşı Dreyfus'a ateş eden bir militan onu hafif yaralar." (Brown, 1997:799-800; aktaran Baysan, 2002:192).

Aydın olmanın gerektirdiği duyarlı davranış, Zola'nın ne kadar hümanist olduğunu göstermektedir. Onun tanımadığı bir insan için ortaya koyduğu özverili mücadele, dünyanın dört bir yanında yaşanan veya yaşanacak olan her türlü bağnazlığa ve haksızlığa karşı bir esin kaynağı 
olmayı sürdürecektir. Zira aradan bir asırdan fazla bir süre geçmesine karşın, bugün de benzer sorunların birçok ülkede zaman zaman yaşandığına tanık olmak düşündürücü olduğu kadar, insanlığın geleceğini tehlikeye sokma eğilimi olan güç odaklarının hâlâ var olduklarının da kanıtıdır.

\section{Romanın Konusu}

Dreyfus Davası'nda casusluk yaptığı gerekçesiyle suçsuz yere Yahudi kökenli olduğu için birtakım baskı ve tezgah sonucu adaletsizliğe kurban edilen Yüzbaşı Dreyfus'un suçsuzluğunu ortaya çıkarmaya çalışan Zola gibi; Gerçek romanında da ırzına geçilip öldürülen bir Hristiyan Kardeşler Din Okulu öğrencisinin cinayeti ile ilgili sırf Yahudi olduğu için suçlanan laik devlet okulu öğretmeni Simon'un masum olduğu ve bir adaletsizliğe kurban edildiği Marc öğretmen tarafından ortaya çıkarılmaya çalışılmaktadır.

Roman, Jonville köyü ilkokul öğretmeni Marc'ın yaşantısı ile başlar. Karısı Geneviève ve kızı Louise ile birlikte orada yaşarlar. Yazları kaynanası Bayan Berthereau ve kayın validesinin annesi Bayan Duparque'un Maillebois kasabasında onlarla birlikte geçirirler. Eşi Geneviève'in büyük annesi Bayan Duparque aşırı yobazdır ve pazar ayinlerini kaçırmaz. Marc dindar olmamakla birlikte eşini hoşnut etmek istediği ve herkesin düşünce ve inanç özgürlüğüne saygı duyduğu için eşine eşlik etmek amacıyla zaman zaman kiliseye pazar törenlerine gider.

Roman, Maillebois kasabası ilkokulu öğretmeni Simon'un eşinin yeğeni ve Kardeşler Din Okulu öğrencisi Zéphirin adlı çocuğun tecavüz ve cinayete kurban gitmesi olayında laik devlet okulu öğretmeni Yahudi kökenli Simon'un suçlanarak ömür boyu hapse mahkûm edilmesini konu edinir. Simon, yahudi kökenli terzilik yapan bir aile olan Lehmann'ların iki oğlundan birisidir. Babalarının ölümünden sonra Simon öğretmen okuluna giderek öğretmen olmuştur.

Cinayet olayı ile ilgili özelde Maillebois kasabası, genelde tüm Fransa ikiye ayrılır: Bir yanda bağnaz tarikatçı kilise çevrelerinin, basının, bazı siyasetçilerin, zengin iş dünyasından baronların ve bürokratların giriştikleri karalama kampanyaları, diğer yanda Marc öğretmenin önderliğinde Simon'un suçsuzluğuna inanan demokrasi, hoşgörü ve özgür düşünce yanlısı birkaç insanın gerçekleri ortaya çıkarıp adaletin gerçekleşmesi için verdikleri mücadele yer almaktadır. Marc öğretmen olayın yaşandığı kasabaya yerleşerek Simon öğretmenin suçsuz olduğunu ortaya çıkarmaya çalışır.

Tarikatçı çevreler, amaçlarına ulaşabilmek için sürekli karanlık güç odakları olarak çalışmakta, çeşitli para kaynakları yaratmakta, özellikle de 


\section{R. GÜNDAY | 96}

basın ve siyasetçilerin de desteğiyle günden güne daha da güçlenmektedirler. Önemli bir güç haline gelen bu tarikatlar, istedikleri yönde bir toplum yaratmak için birincil hedef olarak eğitim alanına büyük önem vermekte; bu çerçevede bir yandan çok sayıda tarikat okulları açarken, diğer yandan devlet okullarında da yandaşları öğretmenler sayesinde hâkim olmaya çalışmaktadırlar. İkinci planlarının ise devletin tüm kurumlarına kendi adamlarını yerleştirmek suretiyle kadrolaşmak olduğu gözükmektedir. Bu bağlamda, Gerçek romanında yerel mahkemeden yargıtaya kadar tüm yargıya sızan tarikatçı okulların yetiştirdiği öğrencilerin, adaletin gerçekleşmesinde evrensel hukuk ilkelerini hiçe sayarak ve bağımsız davranmayarak tarikatçı çevrelerin istedikleri ve çıkarları doğrultusunda karar verdikleri anlatılmaktadır. Zola, siyasi hesaplar uğruna, gerçek ve doğrulardan yana tavır almayarak sorumluluklarını yerine getirmeyen siyasetçileri de eleştirir romanında.

Simon'u hiçbir kanıt olmamasına karşın çevre baskısı nedeni ile Maillebois kasabası hâkimi tutuklamak zorunda kalır. Daha sonra duruşma sırasında tarikat yanlısı mahkeme başkanı hukuk suçu işleyerek jürinin karar odasına girer, Simon'u suçlu gösterecek düzmece bir mektubu jüriye sunar ve bunun üzerine Simon ömür boyu hapse mahkûm edilir. Karara yapılan itiraz üzerine ikinci kez yargılanan Simon, gerici güçlerin devreye girmesi üzerine ikinci yargılamada da suçlu bulunur ve on yıl hapse mahkûm edilir. Yattığı hapis süresi göz önünde bulundurularak tahliye edilir. Başka bir ile yerleşerek orada ticaretle uğraşmaya başlar. Avukatın ikinci mahkeme kararına da itiraz etmesi üzerine Yargıtay hızlı bir şekilde dava dosyasını ele alır, eski sanığın yeniden mahkeme edilmesine dahi gerek görmeden, Rozan'daki ikinci yargı kararını bozar ve Simon'un suçsuz olduğuna ve bereatine karar verir.

Oysa Marc'ın başından beri tahmin ettiği gibi gerçek suçlu Kardeşler Din Okulu rahip öğretmenlerinden Georgias'dır. Aslında suçluyu başından beri okul müdürü rahip ve tarikatın önde gelen papazları bilmektedir. Hakkı ve adaleti en çok onların gözetmesi gerekirken kendi günahlarını ve suçlarını örtmek için bir masumu kendi dinlerinden değil diye suçlamaları, söz konusu bağnaz çevrelerin gerçek yüzlerini göstermektedir.

İmparatorluk yanlısı tarikatçı kilise çevrelerinin öncülüğündeki güçler, 19. yüzyılda Fransa'yı Ortaçă̆'ın karanlıklarına sürüklemek istemektedirler. Voltaire, Didrot, Montesquieu'nün aydınlanma çağından geriye giden bir Fransa söz konusudur romanda. Fransa geleceğe ve aydınlığa yürümesi gerekirken, gericiliğe prim veren bir ülke konumundadır. 21. yüzyılın başında sözde Ermeni soykırımını inkârı suç 
sayan yasa çıkarmaya çalışması bir kez daha Fransa'nın eski karanlık günlere dönme isteğinin her zaman mümkün olabileceğini göstermektedir.

\section{Adaletin Gücü Yerine Güçlerin Adaleti}

1789 Fransız İhtilalinden sonra Cumhuriyet kurulmuş, ancak siyasal açıdan zaman zaman yönetimde tekrar imparatorluğa dönüldüğü gibi, cumhuriyet rejiminin şekilsel olarak kurulmasına karşın demokratik anlamda gerçek bir cumhuriyet rejimi uzun süre yaşama geçememiştir. Fransız toplumu, krallığın yerine bu kez de tarikatçı kilise papazları ve burjuva sınıfı gibi güçlerin etki ve egemenlikleri altına girmiştir. Bu güç odakları, kamu kurumları, bürokrasi ve siyaset yönetiminde hâkim konuma gelirler. Bunun neticesinde toplumda bir yandan sosyal adaletsizlik hüküm sürerken, diğer yandan da söz konusu güçlerin yargıyı da etkileri altına almaları nedeni ile adaletin gücü değil de güçlerin adaleti tecelli etmeye başlar. Dolayısıyla İhtilal sonrası geçen yaklaşık yüz yıllık süreçte ne beklenen özgürlük ve demokrasi, ne eşitlik, ne kardeşlik ne de adalet gerçek anlamda Fransız toplumunda gerçekleşebilmiştir. Gerçek romanında yaşananlar, Fransız toplumunda Fransız Devriminin sloganı olan "eşitlik, kardeşlik ve özgürlük" ilkelerinin hiç de yaşam bulmadığını delillerle ortaya koymaktadır. Eşitlik yerine egemen güçlerin hâkimiyeti ve baskısı söz konusudur toplumda, buna en çarpıcı örnek Simon davasında egemen güçlerin milli eğitim bakanlığı ve hatta yargıyı etkileri altına alıp istedikleri yönde kararlar çıkartmalarıdır. Oysa eğitim ve adalet en çok eşitliğe gereksinim duyulan alanların başında gelmektedir. Kardeşlik ise ırkçı ve bağnaz Fransız toplumunda bir türlü gerçek anlamda var olmaz. Özgürlüğe gelince, bu da toplumda bazı sınıflar ve Hristiyan Fransızlar için geçerlidir.

Yazar cumhuriyet yönetiminin gerçek anlamda işlevsel olabilmesinin, toplumda demokrasinin, eşitliğin ve adaletin var olmasıyla mümkün olabileceğini ortaya koymaya çalışmaktadır. $\mathrm{Bu}$ hedefe ulaşabilmek için her vatandaşın üzerine düşen sorumluluğu yerine getirmesini, kendisine zarar gelmiyor diye haksızlıklara sessiz kalmamasını istemektedir. 1789 Fransız Devrimi gerçek anlamda ancak eğitim yoluyla halkın bilinçlendirilip verilecek mücadele sonucunda yaratılacak özgür düşünceli, hoşgörülü, demokrasi ve adalet yanlısı nesiller sayesinde yaşama geçirilebilecektir. Bu nedenle "1880-1886 yılları arasında Jules Ferry'nin önderliğinde yapılan eğitim devrimi laik cumhuriyeti güçlendirmeyi hedeflemiştir." (Lucas-Dubreton, 1934: 96-97; aktaran Baysan, 2002:183).

Bir yandan gelir adaletsizliği sonucu günden güne daha da zenginleşen baronlar, diğer yandan açtıkları okullar, kurdukları çeşitli işletmeler ve topladıkları yardımlarla önemli bir ekonomik güç haline gelen 


\section{R. GÜNDAY $\mid 98$}

tarikatlar her alanda etkili olmaya ve toplumu yönlendirmeye ve yönetmeye başlamışlardır. Gerçek romanında baronların nasıl zenginleştiğinden söz edilmekle birlikte özellikle tarikat çevrelerinin nasıl ekonomik, siyasal ve toplumsal güç oluşturdukları ayrıntılı bir şekilde anlatılmaktadır:

"Yobazlarm tuttuğu yol belliydi, sinsi sinsi çalışarak, önce eğitimi yani çocuğu eline geçirecek, sonra da beyinleri uyutarak yetiştirip devlet dairelerine yerleştirdiği bu gelecek kuşak sayesinde cumhuriyeti yiyip bitirecekti. Dünün Fransa'sl, Voltaire'in, Diderot'nun Fransa'sl, devrim Fransa'sl, üç cumhuriyeti yaşamış olan Fransa geleceğe doğru güvenle ilerleyecek yerde, bugünkü şaşkın, yitik, gerici duruma gelmişse bunun nedenini eğitim alanlarına el koyan Cizvitler ve diğer tarikatlarm çocuğu ele geçirmesinde aramak gerekirdi. Otuz yılda öğrencileri üç kat artmış, güçleri alabildiğine çoğalmıştı. Gericiler artık güçlenmişti, dişlerini gösteriyor, kafa tutuyor, ülkenin efendiliğini istiyordu... toplumun bütün kaymak tabakasını, orduyu, mahkemeleri, yönetimi, politikayı eline geçirmiş, gericilik bütün adamlarm buralara yerleştirmişlerdi... laik okulların karşısına din okulları açıyor, hatta kendi yarattı̆̆ı, çıkar uğruna ya da alçaklığından bağnazlı̆̆a koşuşan kadın ve erkek öğretmenler araciliğılala bu laik okullar boyunduruğu altına alıyordu. Gericilik şimdi halkın karşısına dikilmiş, açıkça savaşa başlamıştı. Bu savaşı sürdürebilmek için elbette para gerekliydi ve bütün papazlar ticarete başlamıştı. Söz gelimi yalnizca Bon Pasteur adl tarikatın yillik geliri on iki milyonun üstündeydi... Milyarlarca serveti, sonsuz toprakları vardı irticanın" (G.I, 2003:221-223).

Tarikat çevreleri özellikle halkın dini duygularını ve cahilliğini kullanarak güçlendikleri gibi dini taassubun toplumda hüküm sürmesi için de çaba sarf ederler. St. Antoine de Padeue mezhebi, Sacre-Coeur tarikat1, Cizvitler, Kapüsenler ve Kardeşler tarikatları işbirliği içerisinde özellikle kurdukları okullar aracılığı ile toplumda sürü misali kendi buyruklarından çıkamayacak nesiller yetiştirme çabası içerisindedirler.

Tarikatçı rahipler adeta bir örgüt gibi çalışmakta, milletvekilleri, askerler, öğretmenler, müfettiş, yargıç ve savcı gibi kamu görevlileri ile işbirliği içerisinde bulunmaktadırlar. Papazlar işledikleri suç ve yolsuzluk eylemlerinden çeşitli çıar elde etmekte, ekonomik güç oluşturmakta ve toplumdaki baskıcı güçlerini her geçen gün artırarak sürdürmektedirler. Gerçek romanında yaşananlar, yobazlığın, yolsuzluğun, ahlaksızlığın ve yozlaşmanın boyutunu ve tehlikesini gözler önüne sermektedir. Söz konusu güçler, işbirliği içerisinde hareket ederek toplumu karanlığa doğru sürüklemekte, gerçeğin ortaya çıkması ve adaletin yerini bulmasına engel olmaktadırlar. Simon davasında yaşananlar, suçlunun tarikatçı kilise 
okulunda çalışan öğretmen rahip olmasına rağmen bu boyutun araştırılmayıp iddianamede sadece Simon'un suçlanması karanlık güçlerin yargıyı da etki altına aldıklarını göstermektedir. Zola, "kilise'nin yargı ve halk üzerindeki baskısını korkusuzca eleştirmiştir." (Şeker, 2006:246).

Zéphirin'in öldürüldüğü gece halasının beyi olan Maillebois laik devlet okulu öğretmeni Simon, Beaumont'da bir davete katılır. Saat on buçuk trenini kaçırdığı için altı kilometrelik yolu yaya döner. O gece Kardeşler Din Okulu öğretmeni rahip Gorgias, Marc'ın eşinin büyük annesinin hizmetçisi Pélagie'nin oğlunu saat on sularında evine bırakmıştır. Cinayette yaklaşık bu saatlerde işlenir. Ertesi sabah olayı ilk fark edenler devlet okulu öğretmenlerinden Rouzaire ve Mignot'dur. Rahip Philibin de oradadır, pencereden çocuğun odasına girer ve yerde bulduğu "Birbirinizi seviniz" yazısının baş tarafında rahip Gorgias'ın parafının yer aldığı kısmı hızlı bir hamle ile gizlice kopartır. Olay sabahı Kapüsen Meydanı gittikçe kalabalıklaşır. Savcı, Simon'a öğrencilerine 'Birbirinizi Seviniz' yazdırıp yazdırmadığını sorar. Zira savcıya göre, 'Birbirinizi Seviniz' cümlesinin bir şeyler hatırlatması gerekmektedir. Ancak Simon, hiçbir zaman böyle bir yazı örneği kullanmadığını bildirir. Söz konusu yazının yer aldığı kâğıdın üst kısmının kopartılmış olması yargıç ve savcıyı kuşkulandırır. Sorguda Simon, laik cumhuriyet okullarında öğretmenlerin bu yazı örneklerinin üstüne imza atmadıklarını belirterek okulundan bir yazı örneği gösterip kendisinin yazının alt kısmına mühür vurduğunu söyler. Papaz Philibin, yazının üst köşesindeki harflerin imza olmayıp mürekkep izleri olduğunu iddia eder. Sırayla öğretmen Rouzaire, öğretmen yardımcısı Mignot, papaz Philibin ve rahip Fulgence'ın ifadeleri alınır. Fulgence okulda kendisi dışında Isidore, Lazarus ve Gorgias olmak üzere üç rahip öğretmenin daha olduğunu belirtip, bu konuda bir şey söyleyemeyeceğini ifade eder. Simon on ikiye yirmi kala eve döndügüünü belirtir. Simon'un eşine de kocasının saat kaçta geldiği ve bir şeyler duyup duymadıkları sorulur. Kadın kocasının geldiğinde duvar saatinin on ikiye yirmi kalayı gösterdiğini ve ardından da yattıklarını söyler. Savcı ve yargıç, çevredeki herkesi tanık olarak dinlemek ister. Hristiyan Kardeşler Din Okulu müdürü rahip Fulgence'a okullarında üst tarafı mühürlü bu tür yazı örneğinin kullanılıp kullanılmadığını sorar. Maillebois cumhuriyetçi belediye başkanı Darras, ifadesinde öğretmen Simon'un çalışkan ve dürüst bir insan olduğunu ifade eder. Bürokrasiyi temsilen vali Hennebise ise, halkı kızdırıp tepki almamak için üzerine düşen görevi yapmayıp seyirci kalmayı yeğler. Siyaseti temsil eden milletvekilleri yeniden seçilemeyecekleri kaygısıyla susmayı yeğlerler. 
Eğitim camiasının en üst kesimi olan ve evrensel değerlerin, düşünce ve inanç özgürlügünün savunucusu olması gereken üniversite hocaları da Simon Davası'nda üzerlerine düşen sorumluluğu yerine getiremezler. Başta rektör Forbes olmak üzere, öğretim elemanları olaya adlarının karışmasından korktukları için davaya seyirci kalırlar.

Güvenlikten sorumlu kurum olan ordunun tutumuna gelince, temsilcisi General Jarousse ülkede tam bir temizlik yapılarak vatansız ve dinsizlerin kökünü kazıyıp ülkede tekrar krallık yönetimine geçilmesini savunur. Çünkü "ordu henüz kiliseye bağlıdır. Dreyfus olayı sırasındaki Savaş Bakanı ve Genel Kurmay Başkanı koyu katolik ve kralcı subaylardır... Olaya karışanların hemen hemen hepsi "cizvit yetiştirmesi" ve "cumhuriyet düşmanı" subaylardır." (Zevaes, 1946:214; Baysan, 2002:183). Gerçek romanında subayların tutumundan hareketle "yazar böylece Fransız ordusunun cumhuriyet düşmanlarının yönetiminde olduğunu da belirtmektedir." (Baysan, 2002:188).

Eskiden halkın sorunlarını gündeme taşıyan medya da artık belli güç odaklarının eline geçmiş ve tarafsızlığını yitirmiştir. Güç odakları basını, basın da halkı etkilemekte ve yönlendirmektedir. Bir gün önce Simon'u öven ve savunan Petit Beaumontais gazetesi de, yalan yorum ve varsayımlara dayanarak Simon'u açıkça suçlamaya başlar:

"Neler olup bitmişti, hangi güçlü etki ağır basmıştı, bu zehirli makale neyin nesiydi, halkın yalana susamış cehaletinden yararlanarak Yahudi'yi katil gösteren bu makaleyi kimler yazdırıyordu?... Dünden beri karanlıkta bilinmeyen eller masum bir insanı suçlamak, bilinmeyen suçluyu ise kurtarmak için işliyordu... Şu gazeteye bak... artık o da dürüstlü̆g̈̈nü yitirdi, o da halk aldatmaya başladı... Gericiler ve sermaye onu da ele geçirdi, o da sermayenin, ağababalarının çıkarlarına çalışmaya başladı." (G.I, 2003:99,129-130).

Adaleti savunup insanların haklarını koruması gereken yarg1 da aynı güçlerin etkisindedir. Maillebois'daki çocuk cinayetini sorgulayan yargıç Daix, Simon aleyhine hiçbir delil bulamaz ve ilk önce onu tutuklamaz. Ancak, karanlık güçlerin, yönlendirdikleri basının ve etkiledikleri cahil halkın baskısı neticesinde Simon'un tutuklanması emri çıkartır ve polisler Simon'u evinde hiçbir kanıt bulamamalarına rağmen götürürler: "Şüphesiz Yargıç Daix de soruşturmayı yuvarlayıp geçiştirmek üzere buyruklarını almıştı." (G.I, 2003:116, 127).

Simon tutuklandıktan sonra yargılama sürecinde de rahipler türlü dümenler çevirip cinayetin gerçek suçlularını örtbas etmek ve olayı çıarları için kullanmak konusunda bir tiyatro oyuncusu kadar ustadırlar: 
"Simon hakkında kovuşturmazlık kararı verilmesi imkanı arttıkça kötü haberler almaktan da geri durmuyorlardl. Öte yandan, papazlar topluluğu da ellerinden geleni artlarma koymuyorlardi. Rahip Crabot, Beaumont'a daha sık gitmeye, yöneticiler ve yargıçlarla yemekli toplantılara katılmaya da başlamışlardı. Bu arada üniversiteye uğramayı unutmuyorlardı." (Gerçek, I,s:117).

Gizli güçler, tanıkların da çevrelerini kuşatıp yargıç önünde verecekleri ifadeleri belirlerler. Böylece adaletin gerçekleşmesine engel olurlar. Papaz softaları ve etkisindeki insanlar işi o kadar yobazca bir tutumla ileriye götürerek cinayetin dini inanç farklılığı yüzünden işlendiğini iddia ederler.

Marc gibi David de kardeşinin suçsuzluğuna, cinayeti işleyenin papazlardan biri olduğuna inanır. Ne var ki bunu çevreye kabul ettirip gerçeği ortaya çıkarmak pek de kolay olmaz. Çünkü papazlar hem çevrede çok güçlü hem de kendilerini toplumda hiç kötülük yapmayan adeta Tanrının dokunulmaz kulları olarak kabul ettirmektedirler.

Mahkeme başkanı Gragnon ve Cumhuriyet savcısı Raouel de la Bissoniére de söz konusu güçlerle işbirliği içerisinde Simon'a karşı yanlı davranarak ve davanın jüri üyelerine baskı yaparak Simon'un ömür boyu cezaya çaptırılmasını sağlarlar. Jüri üyeleri belli olduğunda yukarıda sözü edilen güçler, özellikle basın aracılığı ile ve çeşitli insanlarla görüşerek jüri üzerinde baskı kurmaya çalışırlar:

"Jüri üyeleri üstünde korkunç bir baskı başladı. Petit Beaumontais gazetesi adlarını, adreslerini açıklıyor, pis Yahudi'nin defterini dürmezlerse, halkın öcünü alacağın yazıyordu. Üyeler toplu imzalı mektuplar almaya başladılar, evlerine beklenmedik konuklar geldi, "karınızın, çoluk çocuğunuzun hayatını düşünün, aman dikkatli olun" diyorlardı." (G.I, 2003:163).

Simon davasında tanıkların ifadeleri özetle şu şekildedir: Maillebois İlkokulu'nun öğretmen yardımcısı Mignot, durumun önemini kavradığı için daha dikkatli olup işittiği seslerin saatini kesinlikle bilemeyeceğini söyler. Aynı okulun bayan öğretmeni Rouzaire ise daha da insafsızlaşmış, duyduğu seslerle ilgili kesin saat vermekte ve hatta duyduğu seslerin Simon'un sesleri olduğunu ileri sürmektedir. Karanlık odakların oluşturduğu kamuoyu sayesinde insanlar daha önce söyledikleri ifadelerinden dönüp farklı şeyler söylemeye, Simon'un aleyhine oluşturulan kampanyayı destekler konuma gelirler. Rahip Philibin odaya girdiklerinde çocuğu yatağın önünde döşemenin üzerinde bulduklarını söyler. Rahip Fulgence'a gelince bu sözlere Simon'u suçlu gösterecek bir şeyler eklemeye çalışır. Hrıstiyan 
Kardeşler Din Okulu'nun diğer üç papaz öğretmeni de tanık olarak dinlenir. Papaz olunca Gorgias ismini alan Valmirie bahçıvanının oğlu Georges Plumut, cinayetin işlendiği saatte, saat on buçuktan itibaren hücresinde, yatağında olduğunu belirtir. Hristiyan Kardeşler Din Okulu'nun kapıcısı ve o saatte sokakta bulunan iki kasabalı da yalancı tanıklık ederek saat on buçukta Gorgias'ın okulda olduğunu söylerler. Yazı örneğinin üzerinde yazılı imzaya benzeyen harfler nedeniyle gönderildiği bilirkişiler Badoche ve Trabut de yobazlarla işbirliği içerisinde oldukları için yazı örneğinin üstündeki lekenin Simon'un adının ve soyadının baş harfleri olan S ve E olduğunu açıklarlar. Bu kanıyı güçlendirmek için Rahip Philibin söz alarak Simon'un bir dostuna yazdığı mektupta aynı parafı gördügünü iddia eder. Son gün ise savunma tanıkları dinlenir, Marc'ın da aralarında bulunduğu tanıkların hepsi ilkokul öğretmeni Simon'un çok iyi, çok uysal, mesleğine, öğrencilerine, evine ve çocuklarına düşkün birisi olduğunu söylerler. Ancak bunlar içerisinde savunma avukatının özellikle tanık olarak dinlenilmesini istediği müfettiş Mauraisin, üstü kapalı ve kaçamak kelimelerle Simon'un yapısında ikiyüzlülük ve dinsel bölücülük bulunduğunu ima etmeye çalışır. Savunma avukatı Delbos'ya gelince, önce savcının iddialarını çürütür, ardından mahkemenin tutumunu, Hristiyan Kardeşleri, Cizvitleri çok ağır bir şekilde eleştirir. Avukat, cinayeti Hristiyan Kardeşler Din Okulu öğretmenlerinden birisinin işlemiş olabileceğini ifade eder. Gericilere ve işbirlikçilerine yüklenir. Ancak son söz iddia makamı olan savciya verildiğinde, savcı dava jürisinden Yahudi ve sübyancı katil olarak tanımladığı Simon'un kellesini ister. Jüri başkanı olarak kurada adı çıkan dindar ve dürüst bir insan olan mimar Jacquin'in kanıt eksikliğinden söz ettiği söylenir, mahkeme başkanının jürinin kararını yönlendirme hakkı bulunmamasına rağmen, başkan Gragnon jürinin karar odasına girerek, onlara Simon'u suçlu gösteren sahte bir mektup sunar. Mahkeme heyetinin sorularını inceleyen ve tanık ifadelerini dinleyen jüri, kanıtların yetersizliği nedeni ile Simon'a ölüm cezası yerine ömür boyu hapis cezası verir.

Bozuk, kokuşmuş ve baskıcı toplumsal yapıyı devam ettirebilmek için gerici güçler, basın, siyaset ve yargı çevresinden güçlerle işbirliği içerisinde masum insanların cezalandırılmasına ortam hazırlayabilmektedirler: "Bütün egemen çevreler, zavall, suçsuz bir insanı ezmek için birleşmişlerdi. Simon'un suçsuzluğunun ortaya çıkması işlerine gelmezdi, çünkü din adamları, askerler, yargıçlar ve yöneticiler arasındaki sömürücü işbirliği tehlikeye girerdi." (Gerçek, II,s:224).

Öğretmen Marc, en güçlünün en haklı olduğu anlayışına karşıdır. Adaletin olmadığı bir toplumda ne ahlaktan ne de özgürlük ve 
demokrasiden söz edilebilir. Yazara göre, ancak iyi eğitilmiş bireylerden oluşmuş bilinçli nesiller bu egemen güçlerin düzenini ortadan kaldırabilir.

Kırtasiye dükkânı işleten Milhomme eltilerden Alexandre, oğlu Sébastian'ın çok hasta olması üzerine Simon davasında mahkemede delil olabilecek, yeğeni Victor'un Hristiyan Kardeşler Din Okulu'ndan çaldığ 1 "Birbirinizi seviniz" yazılı kâğıdın oğlunun defterinin arasında olmasına rağmen gerçeği söylemeyerek haksızlık yaptıkları için Tanrı'nın kendilerini cezalandırdığını düşünür. Sekiz yıl aradan sonra söz konusu yazı örneğini Bayan Alexandre öğretmen Marc'a verir. Simon'un suçsuzluğunu göstermek için iyi bir kanıttır bu. Öte yandan Simon'un ağabeyi David yaptığı araştırma sonucu, kardeşinin yazdığ 1 iddia edilen düzmece bir mektup sonucu suçlu bulunup cezalandırıldığını öğrenir. Bu iki belgeden yola çıkarak kardeşinin yeniden yargılanmasına uğraşır. Avukat Delbos, Zéphirin olayı davası ile ilgili Adalet Bakanlığına yaptığı itirazda suçlunun Hristiyan Kardeşler Din Okulu öğretmenlerinden rahip Gorgias olduğunu belirtir:

"Hıristiyan Kardeşler Din Okulu'ndan Victor'un çaldığı yazı örneğini sonunda dolaptan çıarıp verdiğini anlattı ve Rahip Gorgias'ın parafı. Hıristiyan Kardeşler Okulu'nun mührünü taşıyan yazı örneğini çıkartıp uzattı. İşte kağıt... İşte küçük Zéphirin'in odasında bulunan kağıttaki yırtık köşe de burası olmalı. Biz Zéphirin'in, tomur ağzına sokulduğunda, burayı dişleyerek kopardığını sanmışık. Yardımoım Mignot, kağıtta bu köşenin varlı̆̆ını şimdi çok daha iyi hatırlıyor, odaya girdiğinde Rahip Philibin kopardı demek... Şimdi iyice bakınız şu parafa. Bu örneğin üstünde çok daha belirgin, çok daha okunakl, işte şu F, şu da G, Frère Gorgias'ın baş harfleri. Pek usta bilirkişiler, Badoche ve Trabut olacak adamlar işte bu harflerin L ve S olduğunu söyleyip, kardeşinizin üstüne yıktılar cinayeti... Evet, Rahip Philibin, katili öğrenince bütün papazlarla birlik olup onu kurtarmaya çalışmış ve suçsuz bir insanı zindana yollamışlardı." (G. I, 2003:392-393).

Yazı örneğinin benzerinin Hristiyan Kardeşler Din Okulu'nda bulunup bulunmadığını arama emri verilir. Okul müdürü rahip Philibin'in odasında arama yapılırken Zéphirin'in odasında bulunan kâğıdın yırtık parçası orada ele geçirilir. Olayın halk tarafından duyulması üzerine Beaumont Kapüsenler bölge başkanı, Hristiyan Kardeşler Okulu Müdürü Philibin'i İtalya'daki bir manastıra gönderir. Cizvit papazı din adamı olmasına rağmen böyle bir haksızlığı yapmaktan çekinmez. Kısa bir süre papazlar şaşkınlık yaşarlar, ardından toparlanarak olayı örtbas etmek için tekrar planlar kurmaya ve girişimlerde bulunmaya başlarlar. Cahil halk hâlâ 
gerçekleri görmeyerek sahtekâr okul müdürü rahip Philibin ve ırz düşmanı katil öğretmen rahip Gorgias'ın haksızlığa uğradığını sanır.

Hristiyan Dininin sözcüsü Hazreti İsa gerçek ve adaleti yaymak için gelmiştir. Bu nedenle gerçek bir dindar olan jüri başkanı mimar Jacquin, yargılama sırasında mahkeme başkanı Gragnon'un karar salonuna girip Simon'un cezalandırılmasında etkili olan kendilerine sunduğu mektubun sahte olduğunu öğrenince vicdan azabı çeker.

Yargıtay Simon davasında kararı bozar. Tarikatçı rahipler, devletin her kademesine sızdıkları için yargıtaydaki adamları aracıllğı ile karar resmen duyurulmadan önce papaz Crabot bu haberi öğrenir, o nedenle Marc ile görüşüp mahkeme başkanı Gragnon'u kurtarmaya çalışır.

Tarikatçı rahipler, Simon davasının yeniden görüleceği Rozan mahkemesine de etkili olmak için girişime geçerler. Rozan'da da tarikatların karanlık gücü hâkimdir. Bu nedenle Simon davasında kimse jüri olmak istemez. Rozan, her an haçlı seferine hazır bir kasaba durumuna gelmiştir:

"Davadan sekiz gün önce Rozan, tam bir savaş alanı olmuştu, dini savaşa hazırlanmayan, dinsiz öğretmenin konuşulmadığ tek bir ev bile yoktu. Zavall jüri üyeleri sokağa çıkmaya korkuyorlardl, evlerine kapanıp kalmışlardı. Hele bir sokağa çıksınlar, neler olmuyordu neler; kaldırımda tanımadıklar adamlar omuz vuruyor, iğrenç ilkokul öğretmenini zindana göndermedikleri takdirde başlarına gelecekleri hatırlatıyorlardı. Öğretmen zindanı boylamazsa ya canlarından, ya mallarından, ya da görevlerinden olacaklardl." (G.II, 2003:142).

Burada da natüralizmin çevrenin insan üzerinde etkisini savunan görüşünü görmek münkündür. $\mathrm{Bu}$ baskıların yanında mahkemeye başkanlık edecek Yargıtay üyesi ve savcı da söz konusu tarikatlarla bağlantı içerisindedir:

"Mahkemeye başkanlık edecek Yargıtay üyesi Guybaraud ve Cumhuriyet savcısı Pacard'la ilgili can sıkıcı şeyler duyuyordu. Guybaraud, Valmarie Cizvitlerinin eski öğrencilerindendi. Mesleğinde yükselişini Cizvitlere borçluydu, çok zengin, sofu, kambur bir kadınla evliydi. Cumhuriyet savcisl Pacard'a gelince eski demagoglardandl, şüpheli olaylara adı karışmış, dinci biriydi. Paris'te iyi bir göreve atanmasını bekliyordu." (G.II,2003:143).

Zola'ya göre, görevde yükselmek ya da iyi bir yere tayin olabilmek için tarikatç̧ların desteğini almak gerekmektedir, bunun gerçekleşebilmesi de onlarla işbirliği içerisinde çalışmayla mümkün olabilmektedir. Her tarafa sızan tarikatçılar, adeta karanlık yer altı örgütü gibi çalışmaktadırlar.

Rozan mahkemesinde savunma avukatı Delbos, Simon'u ilk tutuklayan sorgu yargıcı Daix'e kanaatini sorduğunda, Simon'un suçsuz 
olduğuna inanır, Simon'a ceza veren jüri başkanı da aynı inançtadır. Bu ifadelere rağmen yeniden yargılama sonucunda jüri heyeti, oy çokluğu ile Simon'u yine suçlu bulur. Ancak oy birliği ile hafifletici sebeplerin varlığına karar verir. Sonuçta Simon'a on yıl hapis cezası verilir. Tutucular ikinci yargılama sonunda kutlamalar yapar: "Kasabanın yobaz tayfası çok geçmeden zaferi kutlamaya başladl, cübbeler sevinçten uçuyordu." (G.II,2003:175). Simon'un suçsuzluğunu ve gerçeği ortaya çıarmaya çalışan özgür düşünceli ve hoşgörülü öğretmen ve yöneticileri zor gün bekler.

Avukat Delbos, Simon hakkında Rozan'da verilen ikinci yargılama kararına karşı da Adalet Bakanlığı'na itiraz eder. Nihayet gecikmeyle de olsa adalet yerini bulur:

"Yargıtay, kangrenleşen bu yaranın bir an önce kesilip atılması için davaya olağanüstü bir hızla bakıp, eski sanığın yeniden mahkeme edilmesine gerek bile görmeden Rozan kararını bozdu. Simon'un suçsuzluğuna karar verdi." (Gerçek, II, s: 324).

Tüm romanlarında ezilenden yana tavır koyan Zola, Gerçek romanında da ekonomik güç sahibi tarikatlar, ordu, burjuva ve aristokrat çevrelerin fakir köylü, işçi, memur ve esnaf üzerinde uyguladığı baskı ve yönlendirmelere dikkat çekmektedir. Zola'nın romanında halkın hâkim ve karanlık güçlere boyun eymesinin nedeni, kapitalist toplumda maddi güç ölçüsünde insanların söz sahibi olması anlayışından da kaynaklanmaktadır.

\section{Bağnazlık}

19. yüzyıl Fransız toplumu, 16. yüzyılda benimsediği reformlar ve 18. yüzyılda yaşadığı aydınlanma hareketlerinden geriye doğru gitmeye başlamıştır. Tarikatçı papazlar ordu, eğitim kurumları, siyaset ve özellikle de yargıya adamlarını yerleştirmiş ve toplumu istediği şekle sokma ve yönlendirme noktasında bu kurumların da desteğini almıştır. Hem sermaye güçleriyle işbirliği yapan hem de belli düzeyde ekonomik güç konumuna gelen tarikat kiliseleri sivil toplumu baskı altına almaya başlar. Ayrıca, kendilerine destek veren insanlardan alış veriş yaparlar, böylece toplumda mahalle baskısı da oluşturmuş olurlar.

Zola çağının Fransız toplumunda önemli bir sorun olan dini taasup ve hoşgörüsüzlük sorunlarını ele alır. "Devrimci Fransız halkı, yalanlarla kışkırtılıp çılgın, yobaz bir kitle halini almıştır." (Baysan, 2002: 187). Zola'nın bu romanı tarihsel-siyasal motifler içermenin yanında, toplumsal psikoloji boyutunda, yobaz papazların ve cahil insanların bağnazlığını, acımasızlığı ve ahlaksızlığını da ortaya koymaktadır. Eserinin özünü, tarikatçı papazların yönlendirmesiyle dinsel ve ırksal farklılıkları olan vatandaşların Fransa'da yaşam sürdürmede karşılaştıkları güçlükler oluşturmaktadır. 
Zola, "insalcıl bir perspektifte insanın yok ediliş sorununu gündeme taşır." (Barthèlemy ; www.bmlisieux.com/litterature/gambier/gambie14.htm).

Küçük Zephirin doğduğunda kutsanmaz, hiçbir dinden değildir. Ancak altı yıl sonra Zephirin babası Daniel, çalıştığı fabrikada makinanın dişlileri arasında parçalanır. Bu olaydan sonra büyük korkuya kapılan eşi Marie, bir Yahudi ile evlendiği için Tanrı'nın kendisini cezalandırdığı düşüncesine kapılır ve oğlunu kutsatarak Hristiyan Kardeşler Din Okulu'na verir. Çocuk büyüdükçe kamburlaşır, Marie bunu da kocasının acısını yüreğinden atamadığı için Tanrı'nın cezasının devamı olarak görür. Zéphirin, on bir yaşında Kudas törenine katılacağı yıl annesi ölür. Hanımının kardeşinin oğlu bu yetim çocuğa zor durumda kalmasın diye Simon yardım eder.

Gerçek romanında masum olmasına rağmen eşinin yeğeninin ırzına geçerek öldürmekten suçlanan Yahudi öğretmen Simon'a karşı tarikatçı manastır papazlarının yönlendirmesi ile kamuoyu oluşturulur. Cahil kasaba halkı dini taassup içerisinde Simon'a karşı saldırgan davranışlar sergilerler.

Bayan öğretmen Rouzaire, öğrencilerini kiliseye ve dini törenlere götürdüğü için kendisini herkese kabul ettirmiştir. Kapüsenler, Kardeşler tarikatlarının hepsi onu iyi karşılar. Tarikatçı rahipler, bütün dindarları kendi manastırlarına çekmeye çalışırlar. Devletin resmi kiliseleri böylece güç kaybetmeye başlar. Cizvit papazı Crabot, devletin resmi Saint-Martin Kilisesinin ve Beaumont psikoposunun egemenliğini elinden almaya çalışır. Marc'in eşi Geneviève'in anneannesi Duparque, Marc'a yeni tayin edildiği Maillebois İlkokulu'nda öğretmenlik yapamayacağını, çünkü bu kasabanın sofuların hâkim olduğu bir yer olduğunu, burada özgür düşünceli insanlara yer olmadığını söyler.

Öte yandan Marc'ın daha önce görev yaptığı ve halkı aydınlatmaya çalıştığ 1 Jonville köyünde de artık yeni öğretmeni ve belediye başkanını etkisi altına alan Rahip Cognasse'ın dediği olur. Öyle ki papazın bu zaferi, pazardan pazara tören için gittiği Moreux'de de etkisini gösterir.

Dini taassuptan kaynaklanan çevre baskısı Marc'in hanımı Geneviève üzerinde de etkisini gösterir. Geneviève, büyük annesi ve onun evine gelip giden rahiplerin etkisi ile geçmişteki taasup düşüncelerine döner ve kocasından uzaklaşmaya başlar. Artık iftira sonucu suçsuz yere tutuklanan Simon'u savunan kocasına karşı, Simon düşmanlarının safında yer almaya başlar. Marc'ın on dört yıllık eşi Genéviève, nihayet karnındaki çocuğu ile birlikte eşini ve kızı Louise'i bırakarak evi terk eder. Gerçekte eşi ve kızı onu çok sevmesine rağmen, psikolojisi bozulan kadın, rahiplerin etkisiyle kendisine sürekli günahkâr olarak gösterilen kocasının ve etkisinde büyüyen kızının yanından ayrılır. Böylece karnındaki doğacak çocuğu en 
azından rahiplerin öğretisi doğrultusunda yetiştirecektir. Marc'ın eşi Geneviève büyük annesinin evinde ikinci çocuğunu doğurur. Marc, büyük annenin evine karısı ve oğlunu görmeye gittiğinde ne çocuğunu görebilir ne de eşini onunla görüştürür büyük anne. Çocuk babası Marc'dan habersiz kutsanıp papaz olarak yetiştirilmek üzere evden uzaklaştırılır:

"Çocuk bir iblisin çocuğu değil miydi, Geneviève sanki bir şeytan doğurmuştu, bu yüzden de hemen kutsanıр, büyük yıkımlardan kurtarmak için evden uzaklaştırılmıştı." (G.II, 2003: 25).

Bir devlet okulu olan Maillebois İlkokulu'nda bayan öğretmen Rouzaire ve Marc'tan önce görev yapan öğretmen sinıflara haç sembolü asmışlardır. Marc öğretmen, laik okullarda dini sembollerin bulunmasına insanlar arasında ayırımcılığa neden olabileceği ve tarafsızlığı ortadan kaldırabileceği endişesiyle karşıdır. Sınıfından haç sembolünü kaldırır. Ancak yine Cizvitlerin, Hristiyan Kardeşlerin ve etkiledikleri halkın tepkisiyle karşı karşıya kalır. Laik devlet okulları şeytan yuvası olarak gösterilmeye çalışılır.

Bayan Rouzaire, Maillebois kasabasından Beaumont kentine tayin edilir. Ondan boşalan kadroya Marc'in eski mesai arkadaşı Jonville köyü öğretmeni Bayan Mazeline atanır. Ancak tutucu kasabalı Rouzaire'in yerine özgür düşünceli Bayan Mazeline'in atanmasından rahatsızlık duyarlar. Çünkü önceki onların istediği gibi bir öğretmendir; çocuklarını sürekli kiliseye götürür, sınıfa haç takar, öğrencilerine sınıfta dua ettirir. Özgür düşünceli nesiller yetiştirmek isteyen Mazeline bu tür uygulamalar yapmaz. Tutucu belediye başkanı, Mazeline'i kasabalarında istemediklerini bildirmek üzere akademi müfettişi Le Brazer'e şikayete gider.

Férou'nun tanımıla Maillebois tutucu bir kasabadır. Söz konusu kasabada Simon öğretmen olayı devlet okulu öğretmenlerinin durumunu zora sokacaktır. Ona göre, tutucular bu olaydan din ve ırkçlık adına çıar sağlama planı yaparlar. Férou'nun ağzından tutucuların ve cahil Fransız halkının Yahudilere bakışı şu şekilde özetlenmektedir. "Pis bir Yahudi'yi kurtarmak için gerçeği aramaya değer mi?" (G.I, 2003: 45-46). Öğretmen Férou'ya göre söz konusu tutucular sadece yabanclara karşı 1 rkçılık yapmazlar, aynı zamanda onlar gibi düşünmeyen ya da düşünce ve inanç özgürlüğünü savunan, toplumsal ve bilimsel gelişmeye inanan insanlara, özellikle de laik devlet okullarının eğitim ve öğretimine karşıdırlar. Tutucular, insanlara insan oldukları için değer vermeyip, onları düşünce, inanç ve kökenlerine göre ayırıp farklı davranmaktadırlar. Tarikat mensubu Crabot'nun buyruğu altına giren rahipler topluluğu durmadan vaaz verip Fransa'nın Katolik Hristiyan dışında inanca sahip insanlardan 
arındırılmasını isterler: "Yahudi ve Protestanların diri diri yakılıp, kökünün kazınmasın istiyordu." (G. I,2003:163).

Simon'un kayın pederi Lehmann'ların terzi dükkânına söz konusu olay nedeniyle artık müşterileri uğramaz. Simon tutuklandıktan sonra ailesi de evlerinde toplumsal baskı ve ayırıma maruz kalır:

"El yazması bildiri asılmıştı kasabanın duvarlarına; yurtseverleri, Yahudilerin evlerini yakıp yıkmaya çă̆ırıyordu. *Birkaç gün, hele de bir pazar günü Kapüsen Manastrri'ndaki dinsel törende halk öylesine coşmuş̧u ki, Belediye Başkamı Darras, Trou Sokağı'na nöbetçi dikmek için Beaumont polisine başvurmak zorunda kalmıştı." (G.I,2003:115).

Zola'ya göre Fransız toplumunda Yahudiler horlanmakta, bunun sonucu olarak da Yahudi kökenli Fransız vatandaşları utanç duymaktadır. Buna çarpıcı örnek zengin biri konumunda olan Yahudi Baron Nathan ezilmişlik ve ikinci sınıf vatandaş olma utancından kurtulmak için kızını soylu bir Katolik Fransiz ile evlendirmesi verilebilir. Damadı Hector de Sangleboeuf milletvekili olur. Kızını sadece bir Hristiyan ile evlendirmekle kalmaz, rahip Crabot'nun da etkisi ile kızı dinini değiştirerek hem Hristiyan olur hem de Lia olan adını Marie olarak değiştirir.

Dini bağnazlık ve çıkarlar Fransa'yı diğer işgalci ülkelerle birlikte Osmanlı imparatorluğu topraklarında işgale sevk edip, birçok ülkeyi de kolini durumuna getirmişlerdir. Din, ordu, kapitalist güçler ve siyaset el ele ortaklaşa çalışıp nihayetinde Birinci Dünya Savaşı'na neden olmuşlardır. Bu romanda insanlığın ya da insanca duyguların yok oluşu söz konusudur. Bugünün Avrupasında başta Almanya olmak üzere benzer düşünceler hâkimdir ve Müslümanlar farklı dinden ve ırktan diye diri diri yakılmaktadırlar. Roman yayınlanalı 110 yıl gibi bir asırdan fazla bir zaman geçmesine karşın Avrupa toplumlarında dini taassup ve yabancı düşmanlığı gibi sorunlar hâlâ önemini sürdürmektedir.

\section{Hoşgörü/Hümanizm}

Fransa özgürlük ve hoşgörü konularında sancılı dönemler yaşamıştır. Zola'nın söz konusu romanında bilimsellikten çok toplumsal boyut ve tarihi gerçeklerin kurgusu ön planda bulunmaktadır. Yazar, Fransız toplumunda gerçekte yaşanan bir olayı sanat yoluyla tüm dünyaya duyurmayı ve sorunu evrensel kılmayı başarmıştır. "Toplumsal olanın nesnel fotoğrafını çekmeye çalışan Zola" (sapkaya, dogussarpkaya. blogspot.com/2010_09_01_archive.html) irdelediği toplumsal sorunu tüm çıplaklığı ile ve tezli bir şekilde ortaya koyar. Aslında bu romanda Zola 19. ve 20. yüzyıl genelde Avrupa özelde ise Fransız toplumunda baş gösteren en önemli sorunlardan birisi olan dini ve etnik kökene dayalı ayrımcılık 
tutumundan kaynaklanan ötekileştirme anlayışı ve uygulamalarını gündeme taşımaktadır. (Başoğlu, aktaran Türkeş www.msxlabs.org/.../12095-emile-zola-kimdir-hakkinda.html).

Bağnazlık, hoşgörüsüzlük, ırkçılık ve ötekileştirme gibi konular romanda eleştirilen olumsuz davranışlardır. Kardeşlik, hümanizm, hoşgörü ve adalet gibi müspet değerler ise topluma kazandırılmaya çalışılan romanın başlıca konularıdır. 1789 devrimi sonrası dönemde insani değerler ve hümanizm konusu ihmal edilmiş toplumsal bir sorun olarak varlı̆̆ını sürdürmektedir. Zola cumhuriyetin, demokrasi ve eşitlik olmadığı sürece özgürlük demek de olmadığını göstermeye çalışarak, insanı ve çağdaş değerleri merkeze alan anlayışın ancak hoşgörü anlayışının ve demokrasi kültürünün benimsenmesiyle yaşam bulacağına inanır. Roman kahramanı Marc öğretmene göre, insanlar aynı düşüncede olmasalar da birbirlerini sevip sayabilirler.

Yahudi kökenli Simon'u destekliyor ve sofu papazları suçluyor diye eşinin büyük annesi Marc'1 ve ailesini artık evinden kovar. Bu duruma Marc'ın hanımı üzülür, ancak eşini istemiyor diye artık o da dul annesinin de kaldığı büyük annesinin evine gitmek istemez. Kocası Marc öğretmen, hoşgörülü ve sevgi dolu bir insan olduğu için eşine ailesinden uzak durmamasını, onları ziyarete gitmesini, bu duruma kendisinin kırılmayacağını söyler. Ayrıca eşini sevdiği için pazar ayinlerine giderken ona eşlik eder. Marc pozitif bilimden yana olan ve dini inancı olmayan bir insan olmasına karşın, her türlü inanca saygılı ve hoşgörülüdür.

Zola, toplumsal sorunlara yaklaşımındaki sanatçı hassasiyeti ve kimliği ile sadece Fransa' da değil tüm dünyada birçok yazara, siyasetçiye ve sağduyu sahibi insanlara esin kaynağı olur. Yazarın toplumsal sorunları ele alışında hümanist bir yaklaşım söz konusudur. İnsanların, toplumsal statüsü, dini inancı ya da kökeni nedeni ile ayırıma tabi tutulup haksızlığa uğratılmasına, bir başka deyişle ötekileştirilmesine karşı yoğun mücadele verir. Aydınların, bu tür mücadeleleri Fransız toplumunun bugünkü daha demokratik koşullarını hazırlamıştır.

\section{7. Özgür Düşünceli, Demokrasi ve Adalet Yanlısı Nesiller}

Tarikatçı kilise rahipleri bir yandan kendi işledikleri suç ve günahları kapatmaya çalışırken, diğer yandan da toplumda insanlar arasında kin ve nefret tohumları aşılarlar. Basını da çıkarları uğruna kullanırlar, zaten basının bir kısmı kendi yandaşlarının elindedir. Böylece istedikleri doğrultuda bir toplum oluşturma gayreti içerisindedirler. Birey olduğunun ve özgürlüğünün bilincinde olmayan halk kendi aklı ve düşüncesini kullanmayıp bir sürü gibi güç odaklarının belirlediği yönde 
hareket ederler. Oysa güçlü olanlarla işbirliği yapmak cahilliğin, acizliğin ve zayıflığın göstergesidir, haklı olanlardan yana olmak ise cesur ve adil olmanın gereğidir. Zola'ya göre bu da toplumda insanlara ancak eğitim yoluyla kazandırılabilecek bir değerdir.

Yazara göre demokrasinin yerleşip yaşayabilmesi her şeyden önce bireylerin özgür düşünceli yetişmelerine, adaletin var olabilmesi de demokrasi kültürünü benimsemiş ve insan haklarına saygılı nesillerin yetişmesine bağlıdır. Zola bu hedefe ulaşmada en büyük engel olarak tarikatçı kilise okullarını ve oralarda verilen eğitimi görmektedir. Çözüm yolu olarak da cumhuriyetin laik okullarının yaygınlaştırılarak halkın eğitilip aydınlatılması, kilisenin ve tarikat çevrelerinin eğitimden elini çekmesini göstermektedir. Başarmak için insanların bilincini uyarmanın önemine dikkat çekmekte ve bunda da öğretmenlere rehberlik rolü yüklemektedir. Yazar hem ordu hem de kapitalist ve tarikatçı güçler karşısında bireylerin ezilip yok olmaması ve özgür bireyler olarak yaşayabilmesi için yapılması gerekenlerin bir yol haritasını vermektedir. İnsanı köle durumuna sokmaya çalışan her türlü güce karşıdır. Bunun için de genç nesilleri eğitimli olmaya ve bilinçli mücadeleye çağırmaktadır.

Tarikatçı manastır papazlarının yobazlığı, ordunun ırkçılığı ve halkın cahilliği Fransız toplumunu oluşturan vatandaşlar arasında ayrımcllık ve adaletsizliklerin oluşmasına neden olmaktadır. Bütün bu tutumların sonucu toplumda istenmeyen gerilimler ve huzursuzluklar boy göstermektedir. Yaşananlar, bireylerin mutlu ve huzurlu yaşam sürdürebilmelerinin tek teminatı olan adaletin Fransa'da uygulanmadığının bir göstergesidir. Yazar, Fransız devletinin, adaletin ve demokrasinin kök saldığı, gerçek bir hukuk devleti olmasını arzular. Marc öğretmen, suçlanan kim olursa olsun gerçeğin ve adaletin savunucusudur. Marc'a göre, her suçlu cezasını çekmeli, bu papaz, subay ya da hâkim de olsa fark etmez. Ayrıca papazların inançlı olması yetmez, asıl olan adil ve ahlaklı olabilmeleridir.

Bağnazlık ve adaletsizlik toplumsal barışı ve aydınlık gelecek umutlarını uzun süre törpülemiştir, ancak tüm engellemelere rağmen roman, yazarın arzuladığı hoşgörülü, özgür düşünceli ve adalet yanlısı genç nesillerin filizlenmesiyle ve öğretmen Marc ve diğer eğitim ordusu mensuplarının mutluluğuyla son bulur. Yazarın özgür bireylerden oluşan demokratik toplum yaratma umutları gerçekleşmeye başlar. Zira romanın sonu umutların yeşerdiğini simgeleyen güneşli ilkbahar mevsimiyle biter.

Simon'u savunanlar bedel öderler, ancak toplumsal değişimin de başlamasına ön ayak olurlar. Bunun somut örneklerinden birisi, Maillebois kasabasının yeni belediye başkanı memur Salvin'in üçüncü oğlu sosyalist 
Léon Savin'dir. Kasabayı kalkındırır, kasabada kin ve nefretin yerini hoşgörü ve sevginin almasını ister. O babası gibi korkak ve nemelazımcı değil, sorumluluk duygusuyla davranan bilinçli biridir. Simon'a çektiği acıları unutturmak için bir eser adamak ister. Duvarcının oğlu Auguste ve köylü Bognard'ın kızı Angèle'in çocukları Adrien Doloir iyi bir eğitim görerek mimar olur. $\mathrm{O}$ da Simon'a belediye başkanının armağan olarak yaptıracağı evin planını çizer. Eğitim her alanda meyvesini vermeye başlar. Yazarın aynı aileden farklı kuşaklara yer vererek eğitim sayesinde toplumda gözlemlenen değişimi ortaya koymaya çalıştı̆̆ 1 görülür. Burada mimar olduğu kadar, Yahudi kökenli Simon için bir şey yapmaya çalışması, Adrien'nin önceki kuşak iki dedesinden ne denli farklı düşündüğünü, kendini ne denli geliştirdiğini göstermektedir. Cahil dedelerin, aydın torunları artık toplumda söz sahibi olmaya başlamışlardır. Kuşaktan kuşağa değişim söz konusu, özgür düşünceyle eğitilmiş yeni nesiller daha hoşgörülü, demokrasi ve adalet yanlısıdırlar. Gençlik, Yargıtay'ın son karariyla Simon davasında adaletin yerini bulmasiyla yetinmek istemez. Atalarının yaptığı hatadan dolayı, Simon'a bir armağan vererek ondan özür dilemek, atalarının hatasını onarmak isterler. Adrien, öğretmeni Marc'a kasabada Simon'lara bir ev yapıp, bağışlamak istediklerini söyler. Bu evi Simon'un kayın pederinin yıkılan evinin yerine belediye meclisi kararıla yapmak istediklerini belirtir. Eve belediye meclisinden çıkartacakları kararla şöyle bir yazı da yazarlar:

"Maillebois kasabasında, gerçek ve adaletin bir sembolü olan öğretmen Simon'a, çektiği acıları unutması için armă̆andır." (G.II,2003:345).

Simon davasında, birinci kuşak görevini hiç yapmazken, ikinci kuşak hiç olmazsa hatalarını anlar ve kabul eder. Üçüncü kuşak ise hataların telafisine çalışır. Buradan çıkan sonuç, eğitim meyvelerini uzun uğraşlar sonucu vermekte, ancak bu meyveler çok değerli olmaktadır. Eğitilmiş üçüncü kuşak cesur ve paylaşımcıdır. Yeni nesil, din, ırk, düşünce ya da inanç ayırımı yapmaksızın kardeşçe barış içerisinde yaşamayı başarır. İyi eğitim görmüş üçüncü kuşak, ikinci kuşağı da değiştirir. Simon, törenle kasabaya beklenir. Simon'u savunan sosyalist avukat Delbos içişleri bakanı olmuştur ve o da karşılama töreninde yer alır.

Simon davası, Simon, Marc, David ve Delbos'un onur mücadelesi olur. Bu mücadelenin kazanılmasında en büyük pay eğitimindir. Eğitim yoluyla öğretmenler ordusu, yetiştirdikleri özgür düşünceli, hoşgörülü, demokrasi ve adalet yanlısı nesiller sayesinde geleceğin uygar milletini yaratmaya başlarlar. 
Dolayısıyla Gerçek, bağnazlığa karşı hoşgörüyü, cahilliğe karşı bilimi, etkin güçlerin güdümünde ve tutsağı olarak yaşamak yerine özgür düşünceyi, demokrasiyi ve adaleti önemli değerler olarak bireylere ve topluma benimsetmeye çalışan bir eserdir.

\section{Sonuç}

Gerçek romanında Zola, özelde Fransız genelde Batı toplumlarında boy gösteren dini bağnazlık ve yabancı düşmanlığı nedeni ile yaşanan olaylara ve haksızlılara karşı başkaldırı kampanyası başlatır. Her çağda olduğu gibi Zola'nın yaşadığı dönemde de tarikatçı kiliseler, siyasetçiler ve ordu mensupları çıkarcı egemen güçler, iktidarlarını ve çıkarlarını korumak uğruna her türlü olayları tezgahlayabilmektedirler. Tarikat, siyaset ve sermaye, gerçek ve adaletin karşısına önemli bir engelleyici güç olarak çıkmaktadır. Zola'nın bu romanda öne çıkardığı ahlak anlayışı, tüm insanları insan oldukları için din, ırk ayırımı yapmadan sevme anlayışı olan hümanist anlayış ve evrensel nitelikte adalet anlayışıdır.

Dreyfus Olayı gibi Gerçek romanında ortaya koyduğu tavır, Zola'yı aydın yazar sınıfına koyar. Zola'ya göre toplumda gerçekler ve adalet hâkim kılınmalıdır, ulusların büyüklügünü ancak bunlar sağlayabilir. Adaletin olmadığı bir toplumda gerçek anlamda bir ilerleme de olamaz. Gerçek romanında Yahudi kökenli öğretmen Simon'un uğradığı haksızlığa karşı Marc öğretmenin gösterdiği çaba, düşünce adamı ve eğitimci olmanın ötesinde insan olmanın gerekliliğini ortaya koyan bir davranıştır. Marc öğretmen, yaşanılan haksızlıklara karşı susmayı alçaklık olarak görür.

Hümanist anlayış, insanlar arasında ayrışmayı ve ötekileştirmeyi değil, birleşmeyi ve evrensel kardeşliği öngören değerleri benimser. Epikür, Zenon ve Perikles gibi düşünürlerin hümanist felsefesi, "her şeyin ölçüsü insandır" anlayışına dayanmaktadır. İnsanlara hoşgörü ve yeni düşünce ufukları açma yolunda büyük çabalar sarf eden hümanist yazarlar gibi Zola da Fransız toplumunu saplandığı gericilik ve yabancı düşmanlığ 1 batağından, hoşgörülü, demokrasi ve adalet yanlısı bir toplum kurma anlayışıyla yetişmiş özgür düşünceli nesillerin kurtaracağına inanır. $\mathrm{O}$, gelecekte mutlu, huzurlu ve barış içerisinde bir dünyada yaşamanın uygar toplumlar yaratmakla mümkün olacağı düşüncesindedir. Sonuç olarak Gerçek romanı, demokrasi kültürü ve özgür düşüncenin yerleşmediği toplumlarda her insanın başına gelebilecek bir sorunu ele almaktadır. Gerçek, bireylerden toplumuna, kurumlardan devlet yönetimine toplumun tüm kesimine verilen bir mesajdır. 
Sosyal Bilimler Dergisi 113

\section{Kaynakça}

Achard-Bayle, Guy (2001). « Faits de langue, faits de texte... effets de fiction : des désignations dans les "dispositifs fictionnels"», Revue Fabula, http://www.fabula.org/effet_(consulté en juillet 2006)

Barthèlemy, Guy (2011). www.bmlisieux.com/litterature/gambier/gambie 14.htm, Erişim tarihi: 23.03.2011

Baysan, Gül Tekay (2002). "Dreyfus Davası: Gerçek ve Adalet Savaşçısı Zola", Hacettepe Üniversitesi Edebiyat Fakültesi Dergisi Cilt: 19 / Sayı: 1/ ss, 181-195

Başoğlu, Reha (2011). www.lahuti.com/forum/emile-zola-19044.html, Erişim tarihi: 23.03.2011

Becker, Colette, Gina Gourdin-Servenière ve Véronique Lavielle (1993). Dictionnaire d'Émile Zola, Robert Laffont - Coll Bouquins

Bedel, Jean (2002). Zola assassiné, Flammarion

Brown, F. (1997). Zola; A Life. Papermac

Darcos, X, B.Agard ve M.-F.Boireau (1986). XIXe Sciècle en littérature, Hachette, Paris

Guillemin, Henri (1997). Zola, légende et vérité, Utovie, Collection H.G.

Lucas-Dubreton, J. (1934). Histoire de France IV. de Napoleon a nos jours. Flammarion, s.96-97.

Mitterand, Henri (1990). Zola, l'histoire et la fiction, PUF, Paris

Mitterand, Henri (1995). Zola - La vérité en marche, Découvertes Gallimard

Mourad, François-Marie (2003). Zola critique littéraire, Honoré Champion

Pagès, Alain (2008). Émile Zola - de J'accuse au Panthéon, Editions Lucien Souny

Sacquin, Michèle et al (2002). Zola, Bibliothèque nationale de France - Fayard

Sapkaya, dogussarpkaya (2011). blogspot.com/2010_09_01_archive.html, Erişim tarihi: 24.03.2011

Şeker, Bahattin (2006). "Yeşil Gece ve Gerçek", Hacettepe Üniversitesi Edebiyat Fakültesi Dergisi, Cilt: 23 / Say>: 1 / ss. 243-256 


\section{R. GÜNDAY | 114}

Tadié, Jean-Yves (1970). Introduction à la vie littéraire du XIXe Siècle, Bordas, Paris

Türkeş, A. Ömer (2011). www.msxlabs.org/.../12095-emile-zola-emile-zolakimdir-emile-zola- hakkinda.html, Erişim tarihi: 24.03.2011

Winock, Michel (1999). Le Siècle des intellectuels, Le Seuil, coll. « Points »

Zevaes, A. (1946). Histoire de la ille Republique. Ed. de la Nouvelle Revue Critique.

Zola, Emile (1880). Le Roman expérimental, Fasquelle édition

Zola, Emile (2003). Gerçek, Çev. Erdoğan Alkan, Bordo Siyah, İstanbul.

www.giannaparadiso.com/Pages.aspx?konuID=1, Erişim Tarihi: 10.01.2013

www.gunlukkitap.com/.../1623-gercek-978975885, Erişim Tarihi: 10.01.2013

www.haberbuketi.com/emile-zola-biyografi,16.htm, 14 Şubat 2011, Erişim tarihi: 03.03.2013

www.hikayeler.net/edebiyat/Sanat_Akimi/Naturalizm.asp, Erişim tarihi: 02.03.2013

www.nuveforum.net > ... > Dilbilim > Terimler Sözlüğü > Terimler Sözlüğü, Erişim tarihi: 03.03.2013 